\title{
PENGARUH MINYAK HATI CUMI DAN LESITIN DALAM PAKAN TERHADAP PERKEMBANGAN GONAD UDANG WINDU (Penaeus monodon) ASAL TAMBAK
}

\author{
Muhammad Marzuqi*', Nyoman Adiasmara Giri*) dan Zafril Imran Azwar*)
}

\begin{abstract}
ABSTRAK
Penggunaan pakan yang mempunyai nutrisi lengkap dan seimbang sangat berpengaruh dalam pematangan gonad dan pemijahan induk udang windu. Percobaan ini bertujuan untuk menguji penggunaan minyak hati cumi dan lesitin dalam pakan terhadap pematangan gonad udang windu. Perlakuan yang dicobakan adalah tiga ransum pakan dengan komposisi minyak hati cumi dan lesitin dengan jumlah berbeda yaitu: minyak hati cumi $7 \%(\mathrm{~A})$; minyak hati cumi 4\% + lesitin 3\% (B); lesitin 7\% (C); dan satu pakan komersial sebagai kontrol (D). Percobaan ini menggunakan induk udang windu betina dengan bobot rata-rata $111,70 \mathrm{~g}$ dan jantan 75,20 g. Induk udang dipelihara dalam empat bak beton bervolume $16 \mathrm{~m}^{3}$ dengan kepadatan 20 ekor/ bak. Perbandingan betina dan jantan adalah 1:1. Induk udang dipelihara selama 57 hari hanya dengan pemberian pakan buatan. Untuk mengetahui pengaruh perlakuan pakan, maka pada hari ke-38 dilakukan ablasi mata untuk menentukan kecepatan kematangan gonad. Pada akhir percobaan dilakukan pembedahan gonad untuk menentukan Indeks Gonad Somatik (IGS). Hasil percobaan menunjukkan bahwa perlakuan minyak hati cumi $4 \%+$ lesitin $3 \%$ (B) menghasilkan perkembangan gonad dan pemijahan telur yang lebih cepat dibandingkan perlakuan yang lainnya.
\end{abstract}

\begin{abstract}
Effect of dietary squid liver oil and lecithin on gonadal development of pond reared tiger shrimp, Penaeus monodon broodstock.By: Muhammad Marzuqi, Nyoman Adiasmara Giri and Zafril Imran Azwar

The use of complete and balanced diet is important on gonadal development and spawning of Penaeus monodon broodstock. The purpose of present experiment was to evaluate the effect of dietary squid liver oil and lecithin on gonadal development and spawning of Penaeus monodon broodstock. Three experimental diets were prepared containing different levels of squid liver oil and lecithin, i.e. $7 \%$ squid liver oil $(A) ; 4 \%$ squid liver oil $+3 \%$ lecithin $(B) ; 7 \%$ lecithin $(C)$ and commercial pellet feed as control (D). Tiger shrimp broodstock with average body weight of 111.70 $\mathrm{g}$ for female and $75.20 \mathrm{~g}$ for male were kept in four $16 \mathrm{~m}^{3}$ concrete tanks with density of 20 fish/ tank and ratio of female and male of 1:1. The broodstocks was fed with experimental diets for 57 days. On the $d-38$ all female were eyestalk ablated. At the final of feeding trial, gonado somatic index was measured to evaluate maturity stages. The result showed that addition of $4 \%$ squid liver oil added with $3 \%$ lecithin was the best diet for gonadal maturation of P. monodon.
\end{abstract}

KEYWORDS: Penaeus monodon, squid liver oil, lecithin, gonadal development.

\section{PENDAHULUAN}

Untuk menunjang keberhasilan produksi benur pada pembenihan udang windu, penanganan induk perlu mendapatkan perhatian. Hal ini berkaitan dengan keberhasilan proses kematangan gonad, kualitas dan kuantitas telur serta larva yang dihasilkan. Upaya pendekatan untuk memacu perkembangan gonad telah banyak dilakukan antara lain dengan manipulasi lingkungan, hormon maupun pakan. Namun akhir-akhir ini ketersediaan induk laut semakin sulit dan harganya terus meningkat. Untuk mengantisipasi masalah ini pemanfaatan induk udang asal tambak merupakan salah satu alternatif yang perlu diupayakan. Udang asal tambak dengan ukuran yang besar ( $>80 \mathrm{~g}$ untuk betina) dapat dimatangkan gonadnya dalam bak-bak terkontrol, tetapi kualitas telur dan larvanya belum dapat menyamai dengan yang dihasilkan induk udang asal laut (Ruchimat et al., 1992; Tridjoko et al., 1992; Lante et al., 1993; Hutapea et al., 1993).

Untuk memperbaiki kualitas telur dan larva induk udang asal tambak, beberapa peneliti telah mencoba memperbaiki kondisi induk asal tambak dengan memberikan pakan yang mengandung cukup nutrien yang erat kaitannya dengan proses reproduksi sebelum pematangan gonad. Alava et

\footnotetext{
Peneliti pada Loka Penelitian Perikanan Pantai Gondol, Bali
} 
al. (1993a; 1993b) melaporkan bahwa kandungan lesitin dan vitamin $\mathrm{C}$ dalam pakan berpengaruh terhadap pematangan gonad ( $P$. japonicus) asal tambak. Demikian pula Suwirya \& Marzuqi (1998); Marzuqi et al., 1996; Marzuqi et al., 1997 dalam penelitiannya mendapatkan bahwa fosfolipid, vitamin $\mathrm{E}$ dan vitamin $\mathrm{C}$ dalam pakan berpengaruh terhadap proses perkembangan gonad induk udang windu, $P$. monodon asal tambak. Lebih jauh beberapa peneliti melaporkan bahwa pematangan gonad dan pemijahan udang dipengaruhi oleh kualitas asam lemak dalam pakan udang $P$. setiferus (Lawrence et al., 1979; Middleditch et al., 1980 ) dan udang $P$. japonicus (Teshima \& Kanazawa, 1983; Teshima et al., 1989).

Untuk mendapatkan pakan yang baik dan lengkap maka pada penelitian ini dicoba penggunaan minyak hati cumi dan lesitin yang mengandung n-3 HUFA tinggi dalam pakan untuk pematangan gonad induk udang windu asal tambak.

\section{BAHAN DAN METODE}

Percobaan dilakukan di Loka Penelitian Perikanan Pantai Gondol-Bali. Induk udang windu yang digunakan berasal dari tambak tradisional yang telah diadaptasikan dengan pakan komersial sampai kondisinya baik dan memenuhi syarat untuk percobaan. Bobot awal rata-rata induk udang betina $111,70 \mathrm{~g}$ dan jantan $75,20 \mathrm{~g}$. Induk udang dipelihara dalam empat bak beton volume $16 \mathrm{~m}^{3}$. Masing-masing bak diisi 10 pasang induk dengan perbandingan betina dan jantan 1:1. Bak diisi air laut dengan sistem air mengalir dan dilengkapi dengan aerasi. Perlakuan yang dicobakan berupa tiga ransum pakan dengan kandungan minyak hati cumi dan lesitin yang berbeda dan satu pakan komersial sebagai kontrol. Pakan komersial yang digunakan mengandung protein $38-40 \%$, lemak $5 \%$, serat $3 \%$, abu $17 \%$ dan kadar air $12 \%$.

Bahan dasar yang digunakan sebagai sumber protein dalam formula pakan adalah kasein. Adapun komposisi lengkap pakan percobaan disajikan pada Tabel 1.

Pakan percobaan diberikan dua kali sehari pada pagi dan sore sebanyak $3 \cdot 4 \%$ bobot biomassa. Pencahayaan diatur 12 jam gelap dan 12 jam terang. Agar kondisi induk udang windu tetap sehat maka dilakukan pergantian air sebanyak $125 \%$ per hari dengan penyiponan sisa pakan dan kotoran setiap pagi hari. Induk udang dipelihara selama 57 hari. Untuk mengevaluasi pengaruh pakan percobaan terhadap kematangan gonad

Tabel 1. Komposisi pakan percobaan (\%)

Table 1. Composition of test diet (\%)

\begin{tabular}{lrrr}
\hline \multirow{2}{*}{ Bahan (Ingredient) } & \multicolumn{3}{c}{ Pakan (Diets) } \\
\cline { 2 - 4 } & \multicolumn{1}{c}{ A } & \multicolumn{1}{c}{ B } & \multicolumn{1}{c}{ C } \\
\hline Minyak hati cumi (Squid liver oil) & 7,00 & 4.00 & 0.00 \\
Lesitin kedelai (Soybean lecithin) & 0.00 & 3.00 & 7.00 \\
Kasein (Casein) & 55.00 & 55.00 & 55.00 \\
Arginin-HCl (Arginine-HCl) & 3.00 & 3.00 & 3.00 \\
Sukrosa (Sucrose) & 9.00 & 9.00 & 9.00 \\
Pati (O-Starch) & 3.00 & 3.00 & 3.00 \\
Campuran vitamin (Vitamin mix) & 1.92 & 0.92 & 1.92 \\
Campuran mineral (Mineral mix) & 8.00 & 8.00 & 8.00 \\
Kolesterol (Cholesterol) & 1.00 & 1.00 & 1.00 \\
Glukosamin-HCl (Glucosamine-HCl) & 1.50 & 1.50 & 1.50 \\
Sodium sitrat (Sodium citrate) & 0.50 & 0.50 & 0.50 \\
Sodium suksinat (Sodium succinate) & 0.50 & 0.50 & 0.50 \\
Selulosa (Cellulose) & 1.08 & 2.08 & 2.08 \\
Gluten (Gluten) & 8.00 & 8.00 & 8.00 \\
\hline Jumlah (Total) & 100.00 & 100.00 & 100.00 \\
\hline
\end{tabular}

Keterangan (Note):

A. Minyak hati cumi $7 \%$ ( $7 \%$ squid liver oil)

B. Minyak hati cumi $4 \%+$ lesitin kedele $3 \%$ (4\% squid liver oil $+3 \%$ soybean lecithin)

C. Lesitin kedelai $7 \%(7 \%$ soybean lecithin)

D. Pakan komersial (Commercial pellet feed) 
maka pada hari ke-38 induk udang betina diablasi matanya dan dipelihara kembali hingga 20 hari berikutnya. Pengamatan perkembangan gonad dilakukan setiap hari sejak dilakukan ablasi mata dengan menggunakan senter kedap air. Pada akhir percobaan dilakukan pembedahan terhadap gonad udang untuk menentukan indeks gonad somatik (IGS= bobot gonad/bobot tubuh $\times 100 \%$ ). Di samping itu juga dilakukan pengamatan terhadap tingkat kematangan berdasarkan perkembangan gonad (Motoh, 1981), jumlah telur dan daya tetas telur. Kandungan asam lemak lesitin dan minyak hati cumi dalam ransum pakan dianalisis menggunakan GC Antex 3.000.

\section{HASIL DAN PEMBAHASAN}

Dari hasil pengamatan diperoleh bahwa kecepatan kematangan gonad udang windu asal tambak berbeda dari masing-masing perlakuan pada kondisi tanpa ablasi dan kondisi ablasi mata adalah seperti pada Tabel 2 .
Pada Tabel 2 tampak bahwa pemberian ransum pakan dapat memberikan pengaruh terhadap kecepatan kematangan gonad udang windu asal tambak walaupun tanpa ablasi mata. Pengaruh campuran minyak hati cumi dan lesitin (masing. masing $4 \%$ dan $3 \%$ ) terhadap kematangan gonad udang mulai terlihat pada hari ke-22 hingga hari ke-37. Pada perlakuan ini terdapat dua ekor induk udang mengalami perkembangan gonad tingkat I dan dua ekor lagi mengalami tingkat perkembang. an gonad tingkat II dan tingkat III awal. Bahkan pada hari ke-37 induk udang yang mencapai perkembangan gonad tingkat III awal berhasil memijah, sedangkan gonad induk udang dengan kematangan tingkat II terserap kembali. Jumlah telur yang dihasilkan adalah 6.100 butir dan tidak menetas karena tidak dibuahi oleh induk jantan. Induk yang menghasilkan telur mempunyai ukuran relatif besar, sehingga dalam penggunaan induk untuk keperluan panti pembenihan. Hal ini dapat digunakan sebagai bahan pertimbangan

Tabel 2. Pertumbuhan, sintasan, indeks gonad somatik (IGS) dan pemijahan induk udang windu dengan pakan berbeda

Table 2. Growth, survival rate, gonado somatic index (GSI) and spawning of tiger prawn broodstock fed with experimental diets.

\begin{tabular}{|c|c|c|c|c|c|}
\hline \multirow{2}{*}{ Peubah (Variable) } & & \multicolumn{4}{|c|}{ Pakan (Diets) } \\
\hline & & A & B & C & D \\
\hline Bobot awal (Initial weight) & g & 111.70 & 111.70 & 111.70 & 111.70 \\
\hline Bobot akhir (Final weight) & $\mathrm{g}$ & 102.20 & 98.70 & 98.40 & 112.30 \\
\hline Tingkat Kematangan Gonad & ekor & & & & \\
\hline Gonadal Maturation Stage* & ind. & & & & \\
\hline \multicolumn{6}{|l|}{ - Sebelum ablasi (Before ablation) } \\
\hline$<\mathrm{II}$ & & 2 & 2 & 0 & 0 \\
\hline$>$ II & & 0 & 2 & 0 & 0 \\
\hline \multicolumn{6}{|l|}{ Setelah ablasi (After ablation) } \\
\hline$<\mathrm{II}$ & & 2 & 2 & 0 & 1 \\
\hline$>$ II & & 1 & 0 & 0 & 1 \\
\hline Rata-rata IGS (Average of GSI) & $\%$ & 0.92 & 0.93 & 0.90 & 1.50 \\
\hline $\begin{array}{l}\text { Jumlah udang memijah (Number of } \\
\text { shrimp spawned) }\end{array}$ & $\begin{array}{l}\text { ekor } \\
\text { ind. }\end{array}$ & & & & \\
\hline Jumlah telur (Number of eggs) & & 0 & 6,100 & 0 & 0 \\
\hline Daya tetas (Hatching rate) & $\%$ & 0 & 0 & 0 & 0 \\
\hline Sintasan (Survival rate) & $\%$ & 100.00 & 100.00 & 100.00 & 100.00 \\
\hline
\end{tabular}

" tinghat kematangan gonad menurut Motoh, 1981 (Gonadal maturation stages according to Motoh, 1981). Keterangan (Note):

A. Minyak hati cumi $7 \%(7 \%$ squid liver oil)

B. Minyak hati cumi $4 \%+$ lesitin kedele $3 \%$ (4\% squid liver oil $+3 \%$ soybean lecithin)

C. Lesitin kedelai 7\% (7\% soybean lecithin)

D. Pakan komersial (commercial pellet feed) 
untuk pemilihan mutu induk di samping faktorfaktor lainnya.

Pada pemberian pakan yang mengandung minyak hati cumi $7 \%$, perkembangan gonad tingkat I terjadi pada hari ke-39, namun tidak mengalami perkembangan lebih lanjut. Selanjutnya udang yang diberi pakan yang berisi kandungan lesitin 7\% dan pakan komersial (kontrol) pada kondisi tanpa ablasi mata tidak memperlihatkan perkembangan gonad.

Perkembangan gonad induk udang setelah dilakukan ablasi menunjukkan bahwa kematangan gonad tingkat I pada ransum yang mengandung minyak hati cumi $7 \%$ dan kombinasi minyak hati cumi $4 \%$ dan lesitin 3\% dicapai pada hari ke-3 setelah ablasi. Hanya induk udang yang diberi pakan yang mengandung minyak hati cumi $7 \%$ dapat berkembang hingga tingkat perkembangan II, namun tidak berhasil memijah. Sedangkan induk udang yang diberi pakan komersial, perkembangan gonad tingkat I dicapai pada hari ke-17 setelah ablasi mata. Kematangan gonad induk udang kelompok ini lebih lambat apabila diban- dingkan dengan perlakuan lain pada udang dengan ablasi mata. Hal ini diduga karena nutrien formula pakan komersial khusus digunakan untuk memacu pertumbuhan pada udang di tambak, bukan untuk proses pematangan gonad. Namun bila dilihat dari komposisi asam lemak dari pakan komersial menunjukkan bahwa pakan komersial ini mempunyai susunan asam lemak yang seimbang (Tabel 3). Pada akhir percobaan udang yang diberi pakan komersial hanya satu ekor yang menghasilkan IGS sebesar $1,50 \%$ dan tidak memijah.

Adanya perbedaan respon kematangan gonad pada masing-masing induk udang yang diberi pakan dengan kandungan minyak hati cumi dan lesitin yang berbeda diduga dipengaruhi oleh unsur-unsur penting yang terkandung dalam kedua bahan tersebut. Dari hasil percobaan ini terlihat bahwa ransum pakan yang kekurangan minyak hati cumi atau kekurangan lesitin menghasilkan tingkat kematangan gonad yang kurang baik apabila dibandingkan pakan yang mengan* dung kedua bahan tersebut. Selain sebagai bahan emulsi dari trigliserida dan kolesterol, fosfolipid merupakan komponen dari lipoprotein untuk

Tabel 3. Komposisi asam lemak (\%) dalam pakan percobaan.

Table 3. The fatty acid composition (\%) of experimental.

\begin{tabular}{|c|c|c|c|c|}
\hline \multirow{2}{*}{$\begin{array}{c}\text { Asam lemak } \\
\text { Fatty acid }\end{array}$} & \multicolumn{4}{|c|}{ Pakan (Diets) } \\
\hline & $\mathbf{A}$ & $\mathbf{B}$ & $\mathbf{C}$ & D \\
\hline $14: 00$ & 5.80 & 2.90 & 0.50 & 3.36 \\
\hline $16: 00$ & 14.90 & 16.50 & 16.80 & 16.40 \\
\hline $16: 01$ & 9.05 & 4.56 & - & 6.08 \\
\hline $18: 00$ & 1.41 & 2.33 & 2.51 & 1.87 \\
\hline 18:01 & 18.10 & 15.70 & 13.40 & 13.50 \\
\hline $18: 2 n-6$ & 9.60 & 37.60 & 55.10 & 19.70 \\
\hline $18: 3 n-3$ & 0.84 & 0.85 & - & 2.10 \\
\hline $18: 4 n-3$ & 0.40 & 0.31 & - & 0.30 \\
\hline $20: 1 n-9$ & 7.28 & 6.09 & 7.30 & 6.53 \\
\hline $20: 2 n-6$ & 3.14 & 0.85 & 0.15 & 2.53 \\
\hline $20: 3 n-3$ & 7.76 & 3.56 & 0.80 & 5.74 \\
\hline $20: 4 n-4$ & - & - & $\cdot$ & - \\
\hline $20: 5 n-3$ & 11.50 & 15.50 & 1.20 & 9.50 \\
\hline $22: 1 n-9$ & 0.92 & 0.23 & 0.45 & 1.20 \\
\hline $22: 5 n-3$ & 1.30 & 0.42 & 0.54 & 0.95 \\
\hline $22: 6 n-3$ & 6.52 & 2.85 &. & 12.20 \\
\hline $\begin{array}{l}\text { Jumlah lemak } \\
\text { Total lipid (mg/g) }\end{array}$ & 74.50 & 72.10 & 71.10 & 58.00 \\
\hline $\begin{array}{l}\text { Jumlah n-3 HUFA } \\
\text { Total } n-3 H U F A\end{array}$ & 23.30 & 20.50 & 2.16 & 25.60 \\
\hline $\begin{array}{l}\text { Jumlah } n-6 \text { asam lemak } \\
\text { Total } n-6 \text { fatty acid }\end{array}$ & 13.50 & 39.30 & 55.50 & 22.60 \\
\hline
\end{tabular}




\title{
ANALISIS INVESTASI BEBERAPA TINGKAT PADAT TEBAR BERONANG LADA (Siganus guttatus) PADA POLIKULTUR DENGAN UDANG WINDU (Penaeus monodon)
}

\author{
Haseng Padda*) dan Muhammad Tjaronge*)
}

\begin{abstract}
ABSTRAK
Polikultur udang windu dan beronang merupakan salah satu di antara sekian banyak cara untuk meningkatkan produksi, produktivitas dan pendapatan petambak. Penelitian bertujuan mengetahui investasi yang menguntungkan dari polikultur udang windu dan beronang pada beberapa kepadatan tebar. Penelitian menggunakan rancangan acak lengkap dengan empat perlakuan dan tiga ulangan. Kepadatan tebar perlakuan A adalah benur $40.000 \mathrm{ekor} / \mathrm{ha} / \mathrm{musim}$ tanam tanpa beronang, perlakuan B, C dan D adalah benur 40.000 ekor + benih beronang masing-masing 2.000, $4.000 \mathrm{dan} 6.000 \mathrm{ekor} / \mathrm{ha} / \mathrm{musim}$ tanam (110 hari). Produksi perlakuan A mencapai $203,20 \mathrm{~kg}$ udang, B 411,60 kg udang + $160 \mathrm{~kg}$ beronang, C 290,20 kg udang + $192 \mathrm{~kg}$ beronang dan D $159 \mathrm{~kg}$ udang $+122 \mathrm{~kg}$ beronang/ha/musim tanam. Hasil analisis investasi menunjukkan bahwa hanya perlakuan B yang menguntungkan dengan Net Present Value (NPV) 18.384,58; Net Benefit/Cost (Net B/C) 3,21; dan Internal Rate of Return (IRR) 106,63\% yang disebabkan harga jual udang perlakuan B cukup tinggi yaitu Rp $21.000,00 / \mathrm{kg}$
\end{abstract}

\begin{abstract}
Investment analysis of the several stocking densities of rabbit fish, Siganus guttatus polycultured with tiger prawn, Penaeus monodon. By: Haseng Padda and Muhammad Tjaronge.

Polyculture of tiger prawn and rabbit fish is one of the alternative methods to increase production, productivity and farmer income. The purpose of this study was to identify the most profitable investment of tiger prawn and rabbit fish polyculture at different stocking densities. The experiment was arranged in a completely randomized design with four treatments with each three replications. Stocking density of treatment $A$ was 40,000 tiger prawn fry without any rab. bit fish and those of treatments $B, C$ and $D$ were 40,000 tiger prawn fry $+2,000 ; 4,000$ and 6,000 rabbit fish fry/ha/season (110 days), respectively. The productions per ha per season were A: tiger prawn $203.20 \mathrm{~kg}$; B: tiger prawn $411.60 \mathrm{~kg}+$ rabbit fish $160 \mathrm{~kg}$; C: tiger prawn $290.20 \mathrm{~kg}+$ rabbit fish $192 \mathrm{~kg}$ and D: tiger prawn $159 \mathrm{~kg}+$ rabbit fish $122 \mathrm{~kg}$. Investment analysis showed that treatment B was profitable with Net Present Value (NPV) 18,384.58; Net Benefit /Cost (Net/ C) 3.21; and Internal Rate of Return (IRR) $106.63 \%$. The high return in this treatment was due to high selling price of shrimp at treatment B which was $R p 21,000.00 / \mathrm{kg}$.
\end{abstract}

KEYWORDS: investment analysis, Siganus guttatus, Penaeus monodon, polyculture.

\section{PENDAHULUAN}

Polikultur udang windu dan beronang merupakan salah satu cara untuk meningkatkan produksi, produktivitas tambak dan pemanfaatan lingkungan secara optimal serta meningkatkan pendapatan petambak. Manfaat polikultur yaitu menjamin proses produksi dan memberikan nilai tambah melalui pemanfaatan relung ekologi (Suryana, 1987). Selanjutnya tambak merupakan satu diantara media untuk polikultur komoditas bernilai ekonomis tinggi termasuk antara lain beronang dan udang windu (Poernomo, 1986).

Kebiasaan beronang yang hidup berkelompok sangat menguntungkan bila dibudidayakan di tambak karena tidak memerlukan lahan yang luas. Udang windu hidup di dasar tambak sehingga kolom air di atasnya kurang dimanfaatkan secara efisien. Penambahan beronang yang diperkirakan dapat memanfaatkan relung ekologi yang belum dimanfaatkan udang windu diharapkan dapat meningkatkan produktivitas tambak.

Beronang memanfaatkan makanan alami berupa lumut di tambak yang tidak dimanfaatkan udang, sedangkan udang memanfaatkan detritus (jasad-jasad renik yang mati) sebagai makanan yang tidak dimanfaatkan oleh beronang. Polikultur nila merah dan beronang di keramba jaring apung ternyata cukup efektif untuk menanggulangi atau mencegah perkembangan biofouling termasuk lumut (Tonnek et al., 1993). Selanjutnya dikemukakan bahwa bobot kering biofouling pada monokultur nila merah $7.12 \mathrm{~g} / 10 \mathrm{~m}^{2} /$ bulan, sedangkan bobot kering pada polikultur nila merah dan

"Peneliti pada Balai Penelitian Perikanan Pantai, Maros 
beronang hanya $1.2 \mathrm{~g} / 10 \mathrm{~m}^{2} /$ bulan yang kebanyakan berupa partikel atau suspensi.

Penelitian ini bertujuan mengetahui investasi yang menguntungkan dari polikultur udang windu dan beronang pada beberapa kepadatan tebar.

\section{BAHAN DAN METODE}

Penelitian dilakukan di Instalasi Tambak Percobaan Balai Penelitian Budidaya Pantai Marana, Maros, Sulawesi Selatan pada bulan November 1993 s/d Februari 1994. Jumlah petakan yang digunakan 12 buah @ $500 \mathrm{~m}^{2}$. Penelitian menggunakan rancangan acak lengkap dengan empat perlakuan dan tiga ulangan. Ukuran benih beronang (Siganus guttatus) 21,6 g/ekor diperoleh dari nelayan di Kabupaten Takalar, sedangkan benur udang windu (Penaeus monodon) PL-17 diperoleh juga dari Kabupaten Takalar. Kepadatan tebar benih beronang perlakuan B, C dan D masing-masing $100,200,300$ ekor $/ 500 \mathrm{~m}^{2}$ atau $2000,4.000,6.000$ ekor/ha dan benur masing. masing 2.000 ekor $/ 500 \mathrm{~m}^{2}$ atau 40.000 ekor/ha/ musim tanam selama 110 hari. Sebagai kontrol adalah perlakuan $\mathrm{A}$ dengan kepadatan tebar benur 40.000 ekor/ha/musim tanam.

Persiapan tambak meliputi perbaikan pematang dan pintu air, pengolahan tanah dasar, pengeringan, pengapuran dengan dosis $1.000 \mathrm{~kg} /$ ha, pemberantasan hama menggunakan saponin dengan dosis $20 \mathrm{mg} / \mathrm{L}$ dan pemupukan digunakan urea dan TSP $=2: 1(\mathrm{~kg})$. Air dimasukkan secara bertahap sampai pakan alami tumbuh dengan normal kemudian dilakukan penebaran benur dan bibit beronang. Penebaran benur lebih awal 30 hari, maksudnya supaya masih ada kesempatan melakukan pemberantasan ikan liar dengan menggunakan saponin sebelum penebaran bibit beronang.

Dari hasil penelitian tersebut, maka penulis melakukan analisis investasi dari perlakuan yang menguntungkan, sebagai pegangan bagi yang berminat utamanya petambak dalam menginvestasikan modalnya pada sistem polikultur udang windu dan beronang.

Metode analisis investasi dilakukan dengan menghitung indikator berikut (Saleh, 1990):

$$
\text { Net Present Value }(N P V)=\text { Present Value }(\text { PV }) \text { Benefit }- \text { PV Cost }
$$
di mana:

- NPV adalah nilai bersih uang saat ini dari Benefit (Proceeds) dan Cost (Outlays).
- PV Benefit adalah nilai uang saat ini dari Benefit - PV Cost adalah nilai uang saat ini dari Cost

Bila NPV $>0$ berarti menguntungkan, sebaliknya, bila NPV < 0 berarti merugikan dan bila NPV $=0$, maka PV Benefit $=$ PV Cost.

Net Benefit $/$ Cost $($ Net $B / C)=\frac{P V \text { Net B yang positif }}{P V \text { Net B yang negatif }}$

di mana:

$$
=\frac{\operatorname{Net} B}{\operatorname{Net} C}
$$

- Net B/C adalah perbandingan Net B dengan Net C.

- PV Net Benefit $(\mathrm{B})$ yang positif $=\mathrm{PV}$ Net $\mathrm{B}>0$. - PV Net $B$ yang negatif $=$ PV Net $B<0$.

Bila Net $\mathrm{B} / \mathrm{C}>1$ berarti menguntungkan, sebaliknya bila Net $B / C<1$ merugikan dan Net $\mathrm{B} / \mathrm{C}=1$ maka PV Net B yang positif = PV Net B yang negatif atau Net $B=$ Net $C$.

Internal Rate of Return $=i *+\frac{N P V^{\prime \prime}}{N P V^{\prime \prime}-N P V^{\prime}}(i * *-i *)$

IRR adalah suatu tingkat bunga (Discount Rate) yang menunjukkan jumlah nilai sekarang/ nilai netto (NPV) sama dengan jumlah seluruh biaya investasi usaha.

NPV" (NPV positif) $=$ NPV $>0$

NPV' (NPV negatif) $=$ NPV $<0$

$\mathrm{i}^{*}=$ tingkat bunga yang berlaku (15\%).

$i^{\star *}=$ tingkat bunga yang memberi penerimaan nol atau negatif mendekati nol. Dalam hal ini tingkat bunga $108 \%$ memberi penerimaan negatif mendekati nol.

Bila IRR > tingkat bunga yang berlaku berarti menguntungkan, sebaliknya, bila IRR < tingkat bunga yang berlaku berarti merugikan. Bila IRR = tingkat bunga yang berlaku, maka tingkat pengembalian atas kapital yang belum selesai (masih diinvestasikan) hanya menutupi biaya modal (cost of capital).

\section{HASIL DAN PEMBAHASAN}

Hasil penelitian selama satu musim tanam (110 hari) memberikan produksi, laju sintasan, dan konversi pakan seperti yang tertera pada Tabel 1.

Produksi tinggi didapatkan pada perlakuan B, yaitu $20,58 \mathrm{~kg}$ udang $+8 \mathrm{~kg}$ beronang $/ 500 \mathrm{~m}^{2} /$ musim tanam atau $411,60 \mathrm{~kg}$ udang $+160 \mathrm{~kg}$ 
Tabel 1. Produksi, laju sintasan, konversi pakan per $500 \mathrm{~m}^{2}$ per musim tanam polikultur udang windu dan beronang untuk masing-masing perlakuan.

Table 1. Production, survival rate (SR) and food conversion ratio (FCR) per $500 \mathrm{~m}^{2}$ per season of each treatment in the polyculture of tiger prawn and rabbit fish*)

\begin{tabular}{|c|c|c|c|c|c|c|c|c|}
\hline \multirow[b]{2}{*}{$\begin{array}{l}\text { Perlakuan } \\
\text { Treatment }\end{array}$} & \multicolumn{2}{|c|}{$\begin{array}{l}\text { Udang windu } \\
\text { Tiger prawn }\end{array}$} & \multicolumn{6}{|c|}{ Beronang (Rabbit fish) } \\
\hline & $\begin{array}{c}\text { Ukuran } \\
\text { Size } \\
\text { (ind./kg) }\end{array}$ & $\begin{array}{c}\text { Produksi } \\
\text { Production } \\
\text { (kg) }\end{array}$ & $\begin{array}{l}\text { SR } \\
(\%)\end{array}$ & FCR & $\begin{array}{c}\text { Ukuran } \\
\text { Size } \\
\text { (ind./kg) }\end{array}$ & $\begin{array}{c}\text { Produksi } \\
\text { Production } \\
(\mathrm{kg})\end{array}$ & $\begin{array}{l}\text { SR } \\
(\%)\end{array}$ & FCR \\
\hline A & 38 & 10.16 & 19.38 & 1.8 & . & . & . & . \\
\hline B & 32 & 20.58 & 33.28 & 2.1 & 8 & 8.0 & 67.0 & 3.1 \\
\hline $\mathrm{C}$ & 36 & 14.51 & 25.92 & 2.2 & 11 & 9.6 & 53.7 & 3.8 \\
\hline $\mathrm{D}$ & 38 & 7.95 & 15.20 & 2.3 & 28 & 6.1 & 56.4 & 3.0 \\
\hline
\end{tabular}

* Sumber (Source): Tjaronge et al., 1994

$\mathrm{A}=2.000$ benih udang windu (tiger prawn fry)/500 $\mathrm{m}^{2}$

$\mathrm{B}=2.000$ benih udang windu (tiger prawn fry) +100 beronang (rabbit fish fry)/500 $\mathrm{m}^{2}$

$\mathrm{C}=2.000$ benih udang windu (tiger prawn fry) +200 beronang (rabbit fish fry)/500 $\mathrm{m}^{2}$

$\mathrm{D}=2.000$ benih udang windu (tiger prawn fry) +300 beronang (rabbit fish fry) $/ 500 \mathrm{~m}^{2}$

beronang/ha/musim tanam, laju sintasan udang windu dan beronang masing-masing 33,28 dan $67 \%$, konversi pakan masing-masing 2,1 dan 3,10 . (Tabel 1). Perlakuan B yang paling menguntungkan disebabkan: laju sintasan udang windu paling tinggi $(33,28 \%)$ dibandingkan dengan laju sintasan perlakuan A, C dan D masing-masing hanya 19,$38 ; 25,92$ dan $15,20 \%$. Selain itu harga jual udang windu per kg perlakuan B paling tinggi karena ukuran udang dan bobot lebih besar $(31,25$ g/ekor) atau 32 ekor/kg dengan harga jual $\mathrm{Rp}$ $21.000,00 / \mathrm{kg}$ dibandingkan dengan perlakuan $\mathrm{A}$, dan D di mana ukuran udang per ekor lebih kecil (26,32 g/ekor) atau 38 ekor/kg dengan harga jual Rp 18.000,00/kg dan perlakuan C di mana bobot udang per ekor $27,78 \mathrm{~g}$ (36 ekor/kg) dengan harga jual Rp 19.000,00/kg; oleh karena semakin besar ukuran udang per ekor, maka semakin tinggi harga jualnya.

Adapun perbandingan hasil penelitian perlakuan B (Tjaronge et al., 1994) dengan penelitian terdahulu (Tjaronge et al., 1992 dan Burhanuddin \& Sulaeman, 1992) adalah sebagai berikut: Tjaronge et al. (1994) pada polikultur udang windu dan beronang, dengan kepadatan tebar masingmasing, benur 40.000 dan benih beronang 2.000 ekor/ha/ 110 hari memperoleh laju sintasan $33,28 \%$ (udang) dan 67\% (beronang). Rendahnya laju sintasan di sini diduga karena besarnya goncangan kadar garam yang bervariasi antara 6-35 ppt. Tjaronge et al. (1992) menyatakan bahwa dengan kepadatan tebar benur yang sama (40.000 ekor) tetapi benih beronang yang lebih rendah (1.500 ekor/ha/120 hari) memperoleh laju sintasan yang lebih tinggi untuk udang $(63,90 \%)$; tetapi lebih rendah untuk beronang yaitu $55,35 \%$. Burhanuddin \& Sulaeman (1992) pada monokultur beronang dengan kepadatan tebar benih 4.500 ekor/ha/120 hari memperoleh laju sintasan yang lebih tinggi $(87,30 \%)$.

Kegiatan polikultur udang windu dan beronang di tambak membutuhkan biaya variabel (VC) dan biaya tetap (FC). Biaya variabel dibayar sesuai dengan besarnya kegiatan usaha yang terdiri atas benih (benur+beronang), pakan, saponin, kapur, pupuk (urea+TSP), listrik, penggarap, transportasi, upah panen, dan lain-lain, sedangkan krei, saringan dan bambu dimasukkan sebagai biaya variabel karena dianggap hanya dapat digunakan dalam satu musim tanam tertera pada Tabel 2 . Selanjutnya besarnya beban biaya tetap yang harus dibayar walaupun tidak ada kegiatan usaha terdiri atas Pajak Bumi dan Bangunan (PBB), bunga bank dan penyusutan. Penyusutan dihitung secara garis lurus atau nilainya sama setiap tahunnya sesuai umur ekonomis barang modal investasi (Castle et al., 1987) tertera pada Tabel 3.

Adapun kebutuhan modal polikultur udang windu dan beronang per ha dari perlakuan $\mathrm{A}, \mathrm{B}, \mathrm{C}$ dan $\mathrm{D}$ terdiri atas modal investasi masing- masing sebesar $83,78 \%$; $75,72 \% ; 76,86 \%$; dan $80,55 \%$ dan modal kerja masing-masing sebesar $16,22 \%$; $24,28 \% ; 23,14 \%$ dan $19,45 \%$. Modal investasi 


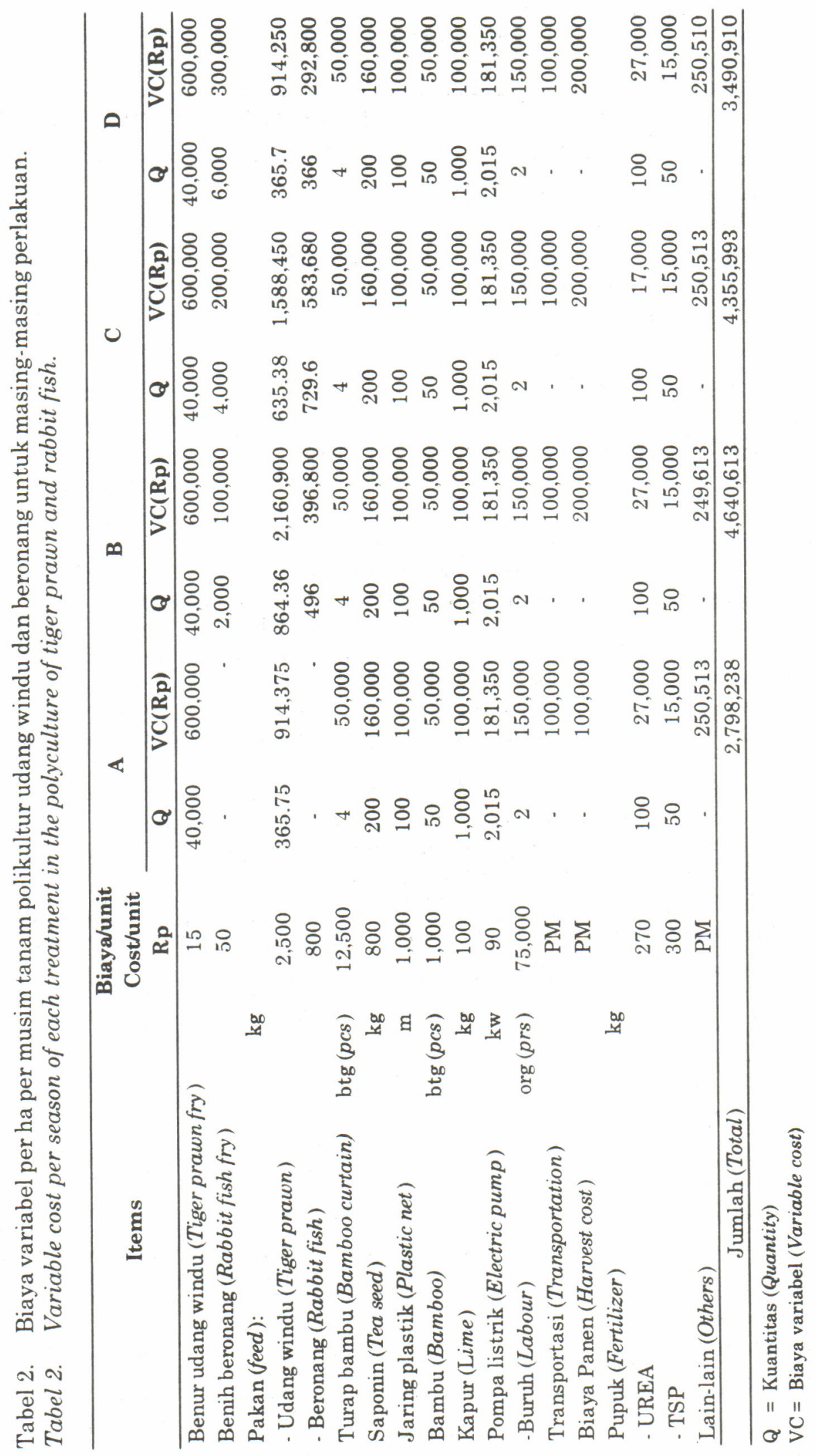


Tabel 3. Biaya tetap per ha per musim tanam polikultur udang windu dan beronang untuk masing-masing perlakuan.

Table 3. Fixed cost per ha per season of each treatment in the polyculture of tiger prawn and rabbit fish.

\begin{tabular}{llrrr}
\hline \multirow{2}{*}{ No. $\begin{array}{c}\text { Biaya tetap } \\
\text { Fixed cost }\end{array}$} & \multicolumn{4}{c}{ Perlakuan (Treatment) (Rp 000) } \\
\cline { 2 - 5 } & \multicolumn{1}{c}{ A } & \multicolumn{1}{c}{ B } & C & D \\
\hline A. Penyusutan (Depreciation) & & & & \\
1. Sewa lahan (Pond lease) & 250.00 & 250.00 & 250.00 & 250.00 \\
2. Konstruksi (Construction) & 200.00 & 200.00 & 200.00 & 200.00 \\
3. Pompa air (Water pump) (10") & 450.00 & 450.00 & 450.00 & 450.00 \\
4. Instalasi listrik (Electric Installation) & 400.00 & 400.00 & 400.00 & 400.00 \\
(16.5 kw) & & & & \\
5. Rumah jaga (Guard house) & 100.00 & 100.00 & 100.00 & 100.00 \\
B. Bunga (Interest) 15\% & $1,087.50$ & $1,087.50$ & 1.087 .50 & $1,087.50$ \\
C. Pajak Bumi dan Bangunan (Tax Land) & 10.00 & 10.00 & 10.00 & 10.00 \\
\hline
\end{tabular}

diasumsikan berasal dari bank dengan tingkat bunga $15 \%$ per tahun dan modal kerja ditanggung petambak dengan tingkat bunga yang sama tertera pada Tabel 4 .

Dalam polikultur udang windu dan beronang, harga input yang mengalami kenaikan dari tahun ke tahun menyebabkan biaya variabel input naik sekitar 5\%/tahun yang diikuti kenaikan nilai penjualan juga sekitar $5 \% /$ tahun dan selanjutnya dilakukan perhitungan rugi dan laba. Perhitungan rugi dan laba polikultur udang windu dan beronang dengan asumsi dua musim tanam (pemeliharaan) per tahun diproyeksikan selama lima tahun sebab investor pada umumnya akan menginvestasikan modalnya selama lima tahun (Padda \& Mangampa,

Tabel 4. Kebutuhan modal investasi dan modal kerja polikultur udang windu dan beronang per ha untuk masing-masing perlakuan.

Table 4. Required investment capital and working capital per ha of each treatment in polyculture of tiger prawn and rabbit fish.

\begin{tabular}{|c|c|c|c|c|c|c|}
\hline \multirow{2}{*}{\multicolumn{2}{|c|}{ Jenis modal (Kind of capital) }} & \multirow{2}{*}{ Unit } & \multicolumn{4}{|c|}{ Perlakuan (Treatment) $(\mathrm{Rp} 000)$} \\
\hline & & & $\mathbf{A}$ & B & C & D \\
\hline \multicolumn{7}{|l|}{ I. Modal Investasi (Investment) } \\
\hline $\begin{array}{l}\text { 1. Sewa lahan } 5 \text { tahun } \\
\text { Pond lease ( } 5 \text { year) }\end{array}$ & ha & 1 & $2,500.00$ & $2,500.00$ & $2,500.00$ & $2,500.00$ \\
\hline $\begin{array}{l}\text { 2. Konstruksi ( } 5 \text { tahun) } \\
\text { Construction ( } 5 \text { year) }\end{array}$ & ha & 1 & $2,000.00$ & $2,000.00$ & $2,000.00$ & $2,000.00$ \\
\hline 3. Rumah jaga (Guard house) & unit $(p c s)$ & 1 & $2,000.00$ & $2,000.00$ & $2,000.00$ & $2,000.00$ \\
\hline 4. Pompa air (Water pump) & unit $(p c s)$ & 1 & $4,500.00$ & $4,500.00$ & $4,500.00$ & $4,500.00$ \\
\hline $\begin{array}{l}\text { 5. Instalasi listrik (Electric } \\
\text { installation) }\end{array}$ & $16.5 \mathrm{kw}$ & PM & $4,000.00$ & $4,000.00$ & $4,000.00$ & $4,000.00$ \\
\hline Subtotal I & & & $14,500.00$ & $14,500.00$ & $14,500.00$ & $14,500.00$ \\
\hline \multicolumn{7}{|l|}{ II. Modal berjalan (Working capital) } \\
\hline 1. Biaya variabel (Variable cost) & & & $2,798.238$ & $4,640.663$ & $4,355.993$ & $3,490.913$ \\
\hline 2. Biaya kas $($ Cash cost $)$ & & & 10.00 & 10.00 & 10.00 & 10.00 \\
\hline Subtotal II & & & $2,808.238$ & $4,650.663$ & 4365.993 & $3,500.913$ \\
\hline Total I + II & & & $17,308.238$ & $19,150.663$ & $18,865.993$ & $18,000.913$ \\
\hline
\end{tabular}


1993). Dengan waktu tersebut biasanya modal investasi sudah bisa kembali dan sudah memper. oleh keuntungan.

Dari hasil perhitungan rugi dan laba ternyata hanya perlakuan $B$ yang menguntungkan yaitu tahun I Rp 4.610.870,00; tahun II Rp 5.091.160,00; tahun III Rp 5.595.470,00; tahun IV 6.125.000,00 dan tahun V Rp 6.681.000,00; sedangkan perlakuan $A$ dan $D$ mengalami kerugian selama lima tahun dan perlakuan $\mathrm{C}$ baru untung pada tahun $\mathrm{V}$ sebesar Rp 153.400,00 sehingga tidak dilanjutkan analisisnya seperti tertera pada Tabel 5 .

Perhitungan Present Value dari Cost dan Benefit perlakuan B disajikan berdasarkan cash flow yakni aliran kas masuk (in flow) dan keluar (out flow) untuk mengetahui Net Cash Flow (aliran kas bersih) tertera pada Tabel 6. Sedangkan NPV dari Cost (outlays) dan Benefit (proceeds) dari Net Cash Flow perlakuan B tertera pada Tabel 7.

Dari Tabel 7 dapat dihitung:

1. NPV positif (NPV pada tingkat bunga $15 \%)=$ $35.036,08-16.651,50=18.384,58$.

NPV negatif (NPV pada tingkat bunga 108\%) $=8.931,86-9.207,64=-275,78$.
2. Net $\mathrm{B} / \mathrm{C}=\left(\mathrm{B}^{\prime \prime} \cdot \mathrm{C}\right) /\left(\mathrm{B}^{\prime}-\mathrm{C}\right)=3,21$

3. $\operatorname{IRR}=15 \%+(108 \%-15 \%)=106,0.63 \%$

Hasil analisis investasi menunjukkan bahwa hanya perlakuan $B$ yang menguntungkan (kepadatan tebar 40.000 ekor benur +2.000 ekor benih beronang/ha/musim tanam) karena NPV positif (18.384,58); Net B/C 3,21 (>1); dan IRR $106,63 \%$ (jauh lebih besar dari tingkat bunga yang berlaku sebesar $15 \%)$. Hal ini merupakan daya tarik petambak dan investor yang akan menanam dan memperluas usahanya. Sejalan pendapat Gittinger (1982), analisis investasi usaha tani dimaksudkan untuk menentukan daya tarik suatu usaha investasi terhadap petani dan pihak lain termasuk masyarakat secara keseluruhan.

Menurut Pasaribu (1995) teknologi budidaya udang windu yang menguntungkan di Jawa Timur adalah semi intensif dengan Net B/C 1,1 dan IRR $21,74 \%$ dengan benefit (nilai penjualan naik $10 \%$ per tahun). Temuan tersebut memperkuat pernyataan bahwa teknologi ekstensif polikultur udang windu dan beronang pada perlakuan $B$ jauh lebih menguntungkan karena Net $\mathrm{B} / \mathrm{C}=3,21(>1,1)$ dan IRR 106,63\% (>21,74\%) dengan biaya variabel dan nilai penjualan naik $5 \%$ per tahun.

Tabel 5. Perhitungan ruga laba polikultur udang windu dan beronang untuk masing-masing perlakuan selama 5 tahun.

Table 5. Profit and loss of each treatment in the polyculture of tiger prawn and rabbit fish for 5 years.

\begin{tabular}{|c|c|c|c|c|c|c|}
\hline \multirow{2}{*}{$\begin{array}{l}\text { Perlakuan } \\
\text { Treatment }\end{array}$} & \multirow{2}{*}{$\begin{array}{c}\text { Rugi/laba } \\
\text { Loss/profit }\end{array}$} & \multicolumn{5}{|c|}{ Tahun (Year) (Rp 000) } \\
\hline & & $\mathbf{I}$ & II & IV & IV & $\mathbf{v}$ \\
\hline A & Rugi (Loss) & $3,276.28$ & $3,190.34$ & $3,100.12$ & $3,005.30$ & $3,905.90$ \\
\hline B & Laba bersih (Net profit) & $4,610.87$ & $5,091.16$ & $5,595.47$ & $6,125.00$ & $6,681.00$ \\
\hline $\mathrm{C}$ & Rugi (Loss) & 759.39 & 547.16 & 325.24 & 91.76 & $153.40^{\star}$ \\
\hline D & Rugi (Loss) & $5,032.83$ & $5,034.72$ & $5,038.71$ & $5,038.79$ & $5,040.98$ \\
\hline
\end{tabular}

* Laba pada perlakuan C didapat pada tahun ke-5 sebesar Rp 153.400, (Profit in treatment $C$ is obtained in year Vabout $R p$ 153,400,-)

Harga pasar udang windu (Market price of tiger prawn) (1994) 1 US $\$=R p 2.197,00$

$\mathrm{B}=32$ Ind. $/ \mathrm{kg} \mathrm{Rp} 21,000.00$

$\mathrm{C}=36$ Ind $. / \mathrm{kg} \mathrm{Rp} 19,000.00$

$\mathrm{A}, \mathrm{D}=38 \mathrm{Ind} . / \mathrm{kg} \mathrm{Rp} 18,000.00$

Beronang (Rabbit fish)/kg Rp 5,000.00 
Tabel 6. Proyeksi cash flow tiap perlakuan selama lima tahun polikultur udang windu 13.171 ekor $(411,60 \mathrm{~kg})$ dan beronang 1.280 ekor $(160 \mathrm{~kg})$.

Table 6. Projection of cash flow for 5 year of each treatment in the polyculture of tiger prawn 13,171 tails $(411.60 \mathrm{~kg})$ and rabbit fish 1,280 tails $(160 \mathrm{~kg})$.

\begin{tabular}{|c|c|c|c|c|c|}
\hline $\begin{array}{l}\text { Items (Year) } \\
\text { (Rp 000) }\end{array}$ & I & II & II & IV & V \\
\hline \multicolumn{6}{|l|}{$\begin{array}{l}\text { A. Aliran kas masuk (In flow): } \\
\text { Revenue }\end{array}$} \\
\hline $1 \mathrm{Udang}$ windu (Tiger prawn) & $17,287.20$ & $18,151.56$ & $19,059.14$ & $20,012.10$ & $21,012.71$ \\
\hline 2 Beronang (Rabbit fish) & $1,600.00$ & $1,680.00$ & $1,764.00$ & $1,952.20$ & $1,944.81$ \\
\hline $\begin{array}{l}\text { B. Total aliran kas masuk } \\
\text { (Total in flow) (A) }\end{array}$ & $18,887.20$ & $19,831.56$ & $20,823.14$ & $21,864.30$ & $22,957.52$ \\
\hline \multicolumn{6}{|l|}{ C. Aliran kas keluar (Out flow): } \\
\hline $\begin{array}{l}1 \text { Masukan biaya variabel } \\
\text { Variable cost input }\end{array}$ & $9,281.33$ & $9,745.40$ & $10,232.67$ & $10,744.30$ & $11,281.52$ \\
\hline $\begin{array}{l}2 \text { Pajak Bumi dan Bangunan } \\
\text { Land and building tax }\end{array}$ & 20.00 & 20.00 & 20.00 & 20.00 & 20.00 \\
\hline \multirow{2}{*}{$\begin{array}{l}\text { D. Total aliran kas kelua } \\
\text { (Total out flow (B) } \\
\text { Net Cash Flow (A-B) }\end{array}$} & $9,301.33$ & $9,765.40$ & $10,252.67$ & $10,764.30$ & $11,301.52$ \\
\hline & $9,585.87$ & $10,066.16$ & $10,570.47$ & $11,100.00$ & $11,656.00$ \\
\hline
\end{tabular}

Tabel 7. Net Present Value dari cost dan benefit perlakuan B polikultur udang windu 13.171 ekor $(411,60 \mathrm{~kg})$ dan beronang 1.280 ekor $(160 \mathrm{~kg})$ selama 5 tahun.

Table 7. Net Present Value of outlays and benefit of treatment $B$ in the polyculture of tiger prawn 13,171 tails $(411.60 \mathrm{~kg})$ and rabbit fish 1,280 tails $(160 \mathrm{~kg})$ of 5 years.

\begin{tabular}{|c|c|c|c|c|c|c|c|c|c|c|}
\hline \multirow{2}{*}{$\begin{array}{l}\text { Thn } \\
\text { Year }\end{array}$} & \multirow{2}{*}{ Outlays } & \multirow{2}{*}{ Proceeds } & \multirow{2}{*}{$\begin{array}{c}\text { DF } \\
15 \%\end{array}$} & \multicolumn{4}{|c|}{ Present Value } & \multirow{2}{*}{$\begin{array}{c}\text { DF } \\
108 \%\end{array}$} & \multicolumn{2}{|c|}{ Present Value } \\
\hline & & & & $\mathrm{C}$ & B & $\mathbf{B}^{\prime}-\mathbf{C}^{\prime}$ & B"-C & & $\mathbf{C}$ & B \\
\hline I & 19.150 .66 & $9,585.87$ & 0.8695 & $16,651.50$ & $8,316.91$ & $8,316.59$ & - & 0.4808 & $9,207.64$ & $4,608.89$ \\
\hline II & & $10,066.16$ & 0.7561 & $\cdot$ & $7,611.02$ & - & $7,611.02$ & 0.2311 & - & $2,326.29$ \\
\hline III & . & $10,570.47$ & 0.6575 & - & $6,950.08$ & - & $6,950.08$ & 0.1111 & - & $1,174.38$ \\
\hline IV & - & $11,100.00$ & 0.5717 & - & $6,345.87$ & - & $6,345.87$ & 0.0534 & - & 592.74 \\
\hline $\mathrm{V}$ & . & $11,656.00$ & 0.4971 & . & $5,794.20$ & - & $5,794.20$ & 0.0257 & - & 229.56 \\
\hline & $19,150.66$ & $52,978.50$ & & $16,651.50$ & $35,036.08$ & $8,316.59$ & $26,701.17$ & & $9,207.64$ & $8,931.86$ \\
\hline $\begin{array}{l}\text { C } \\
\text { B } \\
\text { B'-C } \\
\text { B'-C } \\
\text { DF }\end{array}$ & $\begin{array}{l}=\text { Cost } \\
=\text { Benefit } \\
=\text { Negativ } \\
=\text { Positive } \\
=\text { Discoun }\end{array}$ & $\begin{array}{l}\text { e Benefit } \\
\text { e Benefit } \\
\text { t Factor }\end{array}$ & & & & & & & & \\
\hline
\end{tabular}




\section{KESIMPULAN}

Berdasarkan hasil analisis investasi lima tahun pertama ternyata bahwa hanya perlakuan B (benur 40.000 ekor dan benih beronang 2.000 ekor) yang paling menguntungkan dengan produksi $411,60 \mathrm{~kg}$ udang dan $160 \mathrm{~kg}$ beronang/ ha/musim tanam; laju sintasan masing-masing 33,28 dan $67 \%$ dan konversi pakan masing-masing 2,1 dan 3,1. Perlakuan B menguntungkan karena NPV positif (18.384,58); Net B/C > $1(3,21)$; dan IRR 106,63\% (lebih besar dari tingkat bunga yang berlaku sebesar $15 \%$ ).

\section{DAFTAR PUSTAKA}

Burhanuddin dan Sulaeman. 1992. Pengaruh padat penebaran terhadap pertumbuhan ikan beronang Siganus javus di tambak. Jurnal Penelitian Budidaya Pantai. 8(2): 81-86.

Castle, E., M. H. Backer dan A. G. Nelson. 1987. Farm Business Management. Macmillan Publishing Co., Division of Macmillan, Inc., U.S.A. 413pp.

Gittinger, J. P. 1982. Economic Analysis of Agricultural Project. The John Hopkins University Press, U.S.A. $505 \mathrm{pp}$.

Pasaribu, A. M. 1995. Efisiensi Ekonomi, Alokasi Sumber Daya dan Investasi dalam Pengembangan Teknologi Budidaya Udang Windu (Penaeus monodon) di Jawa Timur. Disertasi untuk memperoleh Gelar Doktor dalam Ilmu Pertanian pada Universitas Negeri Padjadjaran, Bandung. 194 hal.
Padda, H. dan M. Mangampa. 1993. Analisis ekonomi percobaan penggantian air dan lama aerasi dalam budidaya udang windu secara intensif di tambak Marana, Kabupaten Maros, Sulawesi Selatan. Prosiding Seminar Hasil Penelitian Perikanan Pantai, Maros. No. 11: 161.168.

Poernomo, A. 1986. Tambak atau mangrove. Badan Penelitian dan Pengembangan Pertanian Jakarta. Panel Diskusi Daya Guna dan Batas Lebar Jalur Hijau Hutan Mangrove. 27 Februari - 1 Maret 1986, Ciloto. Kontribusi Badan Penelitian dan Pengembangan Pertanian. 19 hal.

Suryana, A. 1987. Pengembangan komoditas ekspor hasil pertanian dengan pendekatan diversifikasi usaha. Jurnal Penelitian dan Pengembangan Pertanian. 6 (1): 18.21.

Saleh. A. K. 1990. Perencanaan dan Evaluasi Proyek KUD. Lembaga Penelitian Univ. Hasanuddin. Ujung Pandang. 34 hal.

Tjaronge M., M. Mangampa, A.G Mangawe dan A. Ismail. 1992. Polikultur udang windu. Penaeus monodon dan ikan beronang. Siganus sp. secara semiintensif di tambak. Jurnal Penelitian Budidaya Pantai. 8 (2) 81.86.

Tjaronge, M., A.G Mangawe dan M. Mangampa 1994. Perbedaan padat penebaran beronang lada, Siganus guttatus dalam polikultur dengan udang windu, Penaeus monodon. Jurnal Penelitian Budidaya Pantai. Maros. 10 (2): 79.

Tonnek, S., D.S. Pongsapan dan Rachmansyah. 1993. Polikultur nila merah dan beronang dalam keramba jaring apung di laut. Jurnal Penelitian Budidaya Pantai, 9 (3): 47.54. 